\title{
The Effect of High School Students' Self-Efficacy and Perceptions for Sun Protection on Their Sun Protection Behaviors
}

\author{
Aslı AKDENIZ KUDUBEŞ*, Murat BEKTAŞ**, Selin KARAKURT****
}

\begin{abstract}
Background: It is important to identify the risks that may cause skin cancer development in adolescents and the factors affecting sun protection behaviors. Objectives: This study was carried out in a descriptive and cross-sectional design to determine the effect of high school students' self-efficacy and perceptions for sun protection on their sun protection behaviors. Methods: The study was conducted from February to April 2019 with 846 students from two high schools in Turkey. The data of the study were collected using a personal information form, the Sun Protection Behavior Scale (SPBS), the Decisional Balance Scale (DBS) for Sun Protection, and the Self-Efficacy Scale for Sun Protection (SES). The data were analyzed through SPSS and AMOS software packages using Pearson's correlation analysis, the linear regression analysis, and the structural equation model. Results: In the multiple regression analysis, a model was created according to the relationship between the variables. In the model, high school students' self-efficacy and perceptions for sun protection explained $33.6 \%$ of their sun protection behaviors. It was found that all the factors except for DBS cons perception ( $p>.05$ ) had a statistically significant effect on students' sun protection behavior. According to the structural equation model, the fit indices of the model were found to be greater than 91. Conclusion: As adolescents' self-efficacy levels and perceptions of the pros and cons increase, their likelihood of exhibiting sun protection behaviors increases as well. In adolescent training, it is important to design and disseminate educational programs consisting of interventions that will increase adolescents' self-efficacy and perceptions of decision-making.
\end{abstract}

Keywords: High School Student, Adolescent, Sun Protection, Sun Protection Behavior, Skin Cancer.

\section{Öz}

\section{Lise Öğrencilerinin Güneşten Korunma Özyeterlilik ve Algılarının Güneşten Korunma Davranışlarına Etkisi}

Giriş: Adölesanlarda cilt kanseri gelişimine neden olabilecek risklerin ve güneşten korunma davranışlarını etkileyen faktörlerin belirlenmesi önem taşımaktadır. Amaç: Bu çalışma, lise öğrencilerinin güneşten korunma özyeterlilik ve algılarının güneşten korunma davranışlarına etkisini belirlemek amacıyla tanımlayıcı-kesitsel olarak yapılmıştır. Yöntem: Araştırma, Şubat-Nisan 2019 tarihleri arasında Türkiye'deki iki lisede öğrenim gören 846 öğrenci ile gerçekleştirildi. Araştırma verilerinin toplanmasında; Tanıtıcı Bilgi Formu, Güneşten Korunma Davranış Ölçeği, Güneşten Korunma Karar Dengesi Ölçeği ve Güneşten Korunma Öz Yeterlilik Ölçeği kullanılmıştır. Araştırma verilerinin analizinde ise SPSS ve AMOS paket programlarından yararlanılarak Pearson korelasyon analizi, doğrusal regresyon analizi ve yapısal eșitlik modeli kullanılmıştır. Bulgular: Çoklu regresyon analizinde değişkenler arasındaki ilişkiye göre bir model oluşturulmuştur. Modelde lise öğrencilerinin güneşten korunma özyeterlilik ve algıları, güneşten korunma davranışlarının \%33.6'sını açıklamaktadır. Güneşten Korunma Karar Dengesi Ölçeği zarar algısı (p> .05) dışındaki tüm faktörlerin güneşten korunma davranışlarını istatistiksel olarak anlamlı şekilde etkilediği bulunmuştur. Yapısal eşitlik modeline göre, modelin uyum indeksleri .91'den büyük olduğu bulunmuştur. Sonuç: Adölesanların özyeterlilik düzeyleri ve yarar-zarar algıları arttıkça, güneşten korunma davranışlarını sergileme olasılıkları da artmaktadır. Adölesanların eğitiminde, öz yeterliklerini ve karar denge algılarını artıracak müdahalelerden oluşan eğitim programlarının tasarlanması ve yaygınlaştırılması önemlidir.

Anahtar Kelimeler: Lise Öğrencisi, Adölesan, Güneşten Korunma, Güneşten Korunma Davranış1, Cilt Kanseri..

Geliş tarihi: 10.07.2020

Kabul tarihi: 23.03.2021

he harmful effects of the sun and the incidence of skin cancers are increasing due to higher levels of ultraviolet radiation

$\mathrm{T}$ reaching the earth; this is because of the thinning of the ozone layer that protects the earth from the sun's rays (1). Although melanoma is rarely encountered in children and adolescents, its incidence is on the rise among the 15- to 19year-old age group). Adolescents (15- to 19-year-olds) have a rare combination of cancer types, including childhood cancers (such as acute lymphocytic leukemia), adult cancers (such as thyroid cancer and skin melanoma), and a greater incidence of lymphoma, according to the American Cancer Society 2020 study (2). Meanwhile, the rate of nonmelanoma skin cancers in 2004 was 20.8 in males and 14.5 in females per 100,000 in the Turkish population (3). However, in 2009 there was an increase to 24.0 in men and 15.8 in women (3). As can be the number of cases of melanoma and nonmelanoma skin cancer in Turkey has increased markedly (3). It has been reported that people who are light-skinned, have red hair, multiple large moles and spots, who are exposed to the sun for long periods of time or are constantly without protection, and who have a history of childhood sunburn are at a greater risk of getting melanoma (4). Although $23 \%$ of lifetime sun exposure occurs before the age of 18, children spend a considerable amount of time outside during the midday hours (5). In addition, tanning is considered fashionable, especially among girls between the ages of 14 and 16 . The idea that tanning is healthy and the increase in vacations and recreational activities heighten the undesirable effects of sunlight on adolescent health (6).

Avoiding the midday sun; staying in the shade; using at least 15-factor sunscreen; wearing a hat, dress, or sunglasses for protection; and staying away from solariums and tanning are recommended sun protection behaviors (1). Nurses play a key role in health protection and development programs so it is important that they do what is necessary to protect adolescents from skin cancer. In health development programs and early disease prevention programs, nurses focus on changing behaviors (7). The transtheoretical model (TTM) provides a conceptual explanation of the processes experienced when people change a problem behavior or behave positively. Its structure consists of three stages: "change stages," "change processes," and "change levels" $(8,9)$. The stages of TTM's transitions were used as a theoretical framework in this analysis. There are five steps in the structure of change: precontemplation, reflection, planning, intervention, and maintenance. These describe a mechanism that takes place from the time a troublesome health pattern is identified and continues to modify this behavior to the point where the behavior is positively displayed $(8,9)$. Authors of these studies have reported that stage-based multiple interventions affect *Bilecik Seyh Edebali University Faculty of Health, Department of Pediatric Nursing, Bilecik, e mail: asliakdeniz@ hotmail.comORCID: 0000-0002-09118182, ** Dokuz Eylul University Faculty of Nursing, Department of Pediatric Nursing, İzmir, e mail: mbekta@gmail.com, ORCID: 0000-0003-33278204,*** Division of Gastroenterology Tepecik Training and Reseaech Hospital, İzmir, e-mail: selinkarakurt@ hotmail.com, ORCID: 0000-0002-6200-6972 
Araştırma

behavioral changes that increase sun protection behaviors among adolescents $(10,11)$.

The TTM, which is frequently utilized in the development of sun protection behaviors, includes cognitive and behavioral processes of individuals, their self-confidence toward change, perceptions of decision-making, and precision measurement tools that capture data on factors that make the change difficult. Self-efficacy, which is one of the tools that determines the level of change, reflects the confidence of individuals in not resuming risky habits when they face challenging situations. High levels of self-efficacy provide the strength to resist resuming old behaviors despite the heavy pressure of inciting situations $(9,12)$. On the other hand, the decisional balance shows the perceptions of the pros and cons of changing behaviors. The pros reflect the positive aspects of behavioral change, while the cons reflect obstacles toward change. For this reason, it is important to measure these variables for identifying individuals who are at different behavioral change stages, planning customized nursing interventions, evaluating the impact of the interventions already applied, and planning new interventions $(9,12)$.

Data, realistic recommendations, and sound science forecasts on the health impact and environmental consequences of ultraviolet (UV) exposure are offered by the WHO INTERSUN Project. It also urges countries to take steps to reduce health risks caused by UV. The initiative offers advice on successful awareness campaigns for national authorities and other organizations and focuses on educating schoolchildren on sun safety (1). Sun protection programs should be implemented and disseminated in schools and pediatric and school health nurses should take a more active role in determining risks that may lead to skin cancer, especially with adolescents (13). Programs applied during adolescence provide positive benefits in preventing skin cancer, as they increase students' self-efficacy and perceptions of the positives regarding sun protection. It was determined that the use of sun protection materials (hats, sun cream, etc.) and knowledge levels of the students whose selfefficacy increased $(10,13)$. Although sun exposure is high and sun protection is at an insufficient level in Turkey, studies investigating sun protection behaviors of high school students, which is rather a risky group, and factors affecting their behaviors are quite limited (13). More investigations are needed to address this gap.

Aim

This study was carried out in a descriptive and cross-sectional design to determine the effect of high school students' selfefficacy and perceptions for sun protection on their sun protection behaviors.

\section{Research Questions}

- What are the mean scores of sun protection self-efficacy and perceptions and sun protection behaviors of high school students?

- What are the correlation between sun protection self-efficacy and perceptions and sun protection behaviors?

- What are the effect of high school students' self-efficacy and perceptions for sun protection on their sun protection behaviors?

\section{Methods}

\section{Study Design}

This was a descriptive and cross-sectional study.

\section{Place and Time of Study}

The study was conducted from February to April 2019 with 851 students from two high schools in Turkey. Five students' forms were removed from the sample due to incomplete filling of the forms, hence the total sample of the study was 846 . The participation rate was $99.5 \%$.

In Turkey, in general high school students wear uniforms suitable for summer and winter months. High school students to go out to the garden in sunny weather during their breakss.

\section{Population and Sampling}

The sampling size required for the study was calculated with GPOWER 3.0 statistical analysis software by taking the Type I error as .05, the Type II error as .20 (power .80), five variables in regression analysis, and the small effect size as .02. Since there was no research to guide the choice of an effect size, a small effect was used for sample size determination. The calculated minimum required sample size was determined as 647 sutudents.

\section{Data Collection Tools}

Data were collected using a personal information form, the Sun Protection Behavior Scale, the Decisional Balance Scale (DBS) for Sun Protection, and the Self-Efficacy Scale for Sun Protection.

The Personal Information Form

The form consists of 12 questions, which are used to obtain descriptive data such as students such as age, gender, economic level, hair-eye-skin color, and skin type.

The Sun Protection Behavior Scale

The Sun Protection Behavior Scale (SPBS), developed in 1998 by Maddock et al., is a 5-point Likert-type scale consisting of 8 items. It is used to measure the sun protection behaviors of individuals. The SPBS examines how often the individual engages in sun protection behavior at times when exposure to the sun is more than 15 minutes. The scale has three subscales, including regular sun avoidance, sunscreen use, and hat use. Higher scores with each item indicate better sun protection behavior. The minimum score on the SPBS is 9; the maximum score is 45 . The validity and reliability study of the scale for the Turkish population was conducted by Aygün and Ergün in 2015. Cronbach's alpha values for the sub-dimensions of sun avoidance, using sunscreen, and wearing a hat were found to be $\alpha=.63, \alpha=.70$, and $\alpha=.70$, respectively. The overall Cronbach's alpha value of the scale is .70. High scores reflect increased sun protection behaviors. Some of the items in the scale are "Avoid the sun during the midday hours," "Use sunscreen," "Wear a hat," etc. $(14,15)$. 
Araştırma

The Decisional Balance Scale (DBS) for Sun Protection

Developed by Velicer et al. and adapted for American adolescents by Maddock et al., DBS is a 5-point Likert-type scale consisting of 8 items. It measures the significance level of participants' sun protection decisions (14, 16). The validity and reliability study of the scale for Turkish population was conducted by Aygün and Ergün in 2014. The scale has two subscales called pros and cons. No total score gets calculated for the scale; instead, the pros and cons are scored separately. Cronbach's alpha values for the perceptions of pros and cons were found to be $\alpha=.76$ and $\alpha=.71$, respectively. The lowest mean score for the perceptions of pros and cons is 4; the highest is 20 . Some of the items include "Sunbathing makes my skin feel good," "I look better when I get tan," etc. (11).

The Self-Efficacy Scale for Sun Protection

This scale was developed by Velicer et al. and adapted for American adolescents by Maddock et al. The scale consists of 9 items including protection from sun exposure, using sunscreen, and wearing hats. It has a 5-point Likert-type scale that is used to measure the degree of participants' self-confidence about sun protection $(14,16)$. The validity and reliability study of the scale for the Turkish population was conducted by Aygün and Ergün in 2014. Cronbach's alpha values for the sub-dimension of avoidance from the sun, using sunscreen, and wearing a hat were found to be $\alpha=.65, \alpha=.84$, and $\alpha=.69$, respectively. The minimum and maximum mean scores that can be obtained from the scale are 9 and 45, respectively. Some of the items in the scale are as follows: "I trust you to use sunscreen even if you don't like it," "I trust you to wear a hat even if no one wears it," etc. (11).

\section{Variables of Study}

Independent Variables: Independent variables of the study; the mean scores obtained from The Decisional Balance Scale (DBS) for Sun Protection and The Self-Efficacy Scale for Sun Protection.

Dependent Variables: The dependent variables of the study; the mean scores obtained from the Sun Protection Behavior Scale.

\section{Data Analysis}

Mean and percentage calculations were used for evaluating the descriptive data. SPSS and AMOS package programs were utilized for the analysis. The significance level was accepted as .05. A Shapiro-Wilk test was used to determine normality of the scale scores. The Pearson correlation coefficient is a measure of the strength and direction of the linear relationship between two variables that Zhou, Deng, Xia, \& Fu, (2016) suggested for the absolute value of r: .00-.19= "very weak;" .20-.39 $=$ "weak;" .40-.59= "moderate;" .60-.79= "strong;" and .80-1.00 = "very strong." Each assumes values in the range of -1 to +1 , where \pm 1 indicates the strongest possible agreement and 0 the strongest possible disagreement (17).

Linear regression analysis was used for analyzing the extent to which sun protection self-efficacy and the perceptions of the pros and cons predicted sun protection behaviors. The structural equation model (SEM) was used for examining the relationship among the variables and standardized coefficients used in the model. Use of the linear regression model allows for understanding how multiple variables affect sun protection behavior as a whole; it does not, however, give the full effect of the relationship among them as relating to sun protection. SEM was used to determine both the effect of these variables together and how the relationship among the variables affected sun protection behaviors.

The research model and sub-dimensions were built based on the World Health Organization's INTERSUN Programme, the guidelines of The American Academy of Dermatology, and data from evidence-based studies $(1,18)$. In the literature, it was found that as students' self-efficacy of sun protection increased, their use of sun protection materials and knowledge levels (hats, sunscreen, etc.) also increased $(10,13)$. The model for this analysis was based on this knowledge found in literature, Moreover, the questionnaire was also based on the research cited in the present report. The literature has mentioned that sun protection behaviour is related to the self-efficacy of sun protection and the expectations of the pros and cons. While several scholars examined one or more of these subdimensions together, it was not possible to locate any research analyzing them all together.

Finally, the Durbin Watson (DW) statistic was used to determine autocorrelation. With this statistic, a value between 1.5 and 2.5 indicates no autocorrelation.

\section{Ethical Considerations}

At the outset, written consents of the authors of the scales used in the study were obtained through email. This study was approved by the Institutional Review Board of the University (IRB approval number: 4475-GOA-2019/03-34) (date: 13.02.2019). In addition, the written institutional approval of the related Provincial Directorate of National Education was obtained. For the data collection process, written informed consents of the students and their parents were obtained. Research and publication ethics were followed in this study.

\section{Results}

The average student age was $15.81 \pm 1.19$ and $57.4 \%$ of them were female. It was found that $35 \%$ of their fathers and $26.8 \%$ of their mothers were university graduates and that $54.8 \%$ of the families had a medium economic level. Also, $39 \%$ of the students had brown hair, $64.1 \%$ had brown eyes, $39.5 \%$ had light skin, and $28.1 \%$ had been sunburned at least once (Table 1 ). 
Table 1. Sociodemographic Characteristics of High School Students

\begin{tabular}{|c|c|c|c|}
\hline & & $\mathbf{n}$ & $\%$ \\
\hline \multirow[t]{2}{*}{ Gender } & Girls & 486 & 57.4 \\
\hline & Boys & 360 & 42.6 \\
\hline \multirow[t]{5}{*}{ Education Status of Father } & Literate & 6 & 0.7 \\
\hline & Primary School & 122 & 14.4 \\
\hline & Middle School & 142 & 16.8 \\
\hline & High School & 280 & 33.1 \\
\hline & University & 296 & 35.0 \\
\hline \multirow[t]{5}{*}{ Education Status of Mother } & Literate & 20 & 2.4 \\
\hline & Primary School & 175 & 20.7 \\
\hline & Middle School & 140 & 16.5 \\
\hline & High School & 284 & 33.6 \\
\hline & University & 227 & 26.8 \\
\hline \multirow[t]{5}{*}{ Economical Situation } & Very Good & 25 & 3.0 \\
\hline & Good & 327 & 28.7 \\
\hline & Middle & 464 & 54.8 \\
\hline & Poor & 21 & 2.5 \\
\hline & Very Poor & 9 & 1.1 \\
\hline \multirow[t]{5}{*}{ Hair Color } & Red & 11 & 1.3 \\
\hline & Yellow & 61 & 7.2 \\
\hline & Light Brown & 238 & 28.1 \\
\hline & Brown & 330 & 39.0 \\
\hline & Black & 206 & 24.3 \\
\hline \multirow[t]{5}{*}{ Eye Color } & Blue & 34 & 4.0 \\
\hline & Green & 83 & 9.8 \\
\hline & Hazel & 118 & 13.9 \\
\hline & Coffee & 542 & 64.1 \\
\hline & Black & 69 & 8.2 \\
\hline \multirow[t]{4}{*}{ Skin Color } & Freckled Light Skin & 32 & 3.8 \\
\hline & Light-Skinned & 34 & 39.5 \\
\hline & Auburn & 292 & 34.5 \\
\hline & Brown & 188 & 22.2 \\
\hline \multirow[t]{6}{*}{ Skin Type } & Easy Burning & 83 & 9.8 \\
\hline & Easy Burnıng Less Bronzing & 148 & 17.5 \\
\hline & Burning & 222 & 26.2 \\
\hline & Less Burning & 207 & 24.5 \\
\hline & Bronze & 174 & 20.6 \\
\hline & No Burn & 12 & 1.4 \\
\hline \multirow[t]{4}{*}{ Sunburn Status } & No & 395 & 46.7 \\
\hline & 1 Times & 238 & 28.1 \\
\hline & 2 Times & 119 & 14.1 \\
\hline & 3 And More Times & 94 & 11.1 \\
\hline
\end{tabular}

The mean score of the Sun Protection Behavior Scale was $18.45+5.33$. The mean scores of the Decisional Balance Scale Pros Perception and Cons Perception were $10.33+3.70$ and $8.83+3.51$, respectively. The mean scores the Self-Efficacy Scale for Sun Protection in the sub-dimensions of avoidance of the sun, using sunscreen, and wearing a hat were $6.78+3.07$, $9.27+4.33$, and $4.13+2.26$, respectively (Table 2 ). 
Araştırma

Table 2. The Mean Scores of Sun Protection Self-Efficacy and Perceptions and Sun Protection Behaviors of High School Students

\begin{tabular}{|c|c|c|c|c|c|}
\hline & $\mathbf{n}$ & Minimum & Maximum & Mean & Std Deviation \\
\hline Sun Protection Behavior Scale & 846 & 8.00 & 51.00 & 18.45 & 5.33 \\
\hline $\begin{array}{l}\text { Decisional Balance Scale } \\
\text { Pros Perception }\end{array}$ & 846 & 4.00 & 20.00 & 10.33 & 3.70 \\
\hline $\begin{array}{l}\text { Decisional Balance Scale } \\
\text { Cons Perception }\end{array}$ & 846 & 4.00 & 20.00 & 8.83 & 3.51 \\
\hline Self-Efficacy Scale for Sun Protection & 846 & 9.00 & 45.00 & 20.19 & 8.06 \\
\hline $\begin{array}{l}\text { Self-Efficacy Scale for Sun Protection -Sun } \\
\text { Avoidance }\end{array}$ & 846 & 3.00 & 15.00 & 6.78 & 3.07 \\
\hline $\begin{array}{l}\text { Self-Efficacy Scale for Sun Protection - } \\
\text { Sunscreen Use }\end{array}$ & 846 & 4.00 & 20.00 & 9.27 & 4.33 \\
\hline $\begin{array}{l}\text { Self-Efficacy Scale for Sun Protection -Hat } \\
\text { Use }\end{array}$ & 846 & 2.00 & 10.00 & 4.13 & 2.26 \\
\hline
\end{tabular}

When the relationship between sun protection self-efficacy and perceptions and sun protection behaviors were examined, a moderate, positive, and highly significant correlation was found between SPBS and DBS pros perception, while there was a low, negative, highly significant correlation between SPBS and DBS cons perception (Table 3). Moreover, there was a moderate, positive, and highly significant correlation between SPBS and SES avoidance of the sun; a moderate, positive, and highly significant correlation between SPBS and SES sunscreen use; and a moderate, positive, and highly significant correlation between SPBS and SES hat use (Table 3).

Table 3. The Correlation between Sun Protection Self-Efficacy and Perceptions and Sun Protection Behaviors

\begin{tabular}{|c|c|c|c|c|c|c|}
\hline & 1 & 2 & 3 & 4 & 5 & 6 \\
\hline 1. Sun Protection Behavior Scale (SPBS) & 1.00 & & & & & \\
\hline 2. DBS-Pros Perception & $.46^{*}$ & 1.00 & & & & \\
\hline 3. DBS-Cons Perception & $-.14 *$ & $-.33 *$ & 1.00 & & & \\
\hline 4. SES-Sun Avoidance & $.37 *$ & $.34 *$ & $-.05^{*}$ & 1.00 & & \\
\hline 5. SES-Sunscreen Use & $.50 *$ & $.46^{*}$ & $-.12 *$ & $.55^{*}$ & 1.00 & \\
\hline 6. SES-Hat Use & $.33 *$ & $.24 *$ & $-.09 *$ & $.48^{*}$ & $.51 *$ & 1.00 \\
\hline
\end{tabular}

In the multiple regression analysis, a model was created according to the relationship between the variables. The effect of high school students' self-efficacy and perception of pros-cons of sun protection on their sun protection behaviors was defined as a model. As the subscale scores obtained from the Sun Protection Self-Efficacy Scale (SES) increased, the sun protection self-efficacy of the students increased as well. As the subscale scores obtained from the Decisional Balance Scale (DBS) for Sun Protection increased, students' perceptions of the pros of sun protection increased and their perception of the cons of sun protection decreased. Furthermore, as the students' total score obtained from the Sun Protection Behavior Scale (SPBS) increased, their sun protection behaviors increased as well. In the model, high school students' sun protection selfefficacy and their perception of pros-cons of sun protection explained $33.6 \%$ of their sun protection behaviors. It was determined that students' perception of pros (DBS), their levels of avoidance from the sun (SES), use of sunscreens (SES), and wearing a hat (SES) increased their sun protection behaviors as much as .261 $(\beta=.261), .078(\beta=.078), .293(\beta=.293)$ and .079 $(\beta=.079)$ times, respectively. It was found that all the factors other than DBS cons perception $(p=.937)$ had a significant effect on sun protection behaviors (Table 4). Also, the DW value was 1.850. There was no autocorrelation. 
Araştırma

Table 4. The Extent to Which High School Students' Sun Protection Self-Efficacy and Their Perception of Pros-Cons Predicted their Sun Protection Behaviors

\begin{tabular}{|c|c|c|c|c|c|}
\hline \multirow{3}{*}{$\begin{array}{l}\text { Decisional Balance Scale (DBS) } \\
\text { and Self-Efficacy Scale (SES) }\end{array}$} & \multicolumn{5}{|c|}{ Sun Protection Behavior Scale (SPBS) } \\
\hline & \multicolumn{5}{|c|}{ Model 1} \\
\hline & $\beta$ & $\begin{array}{c}\text { Coefficients } \\
\text { Standardized } \\
\text { Error }\end{array}$ & $\begin{array}{c}\text { Standardized } \\
\text { Coefficients } \\
\text { Beta }\end{array}$ & $\mathbf{t}$ & $\mathbf{p}$ \\
\hline DBS-Pros Perception & .404 & .049 & .261 & 8.289 & .000 \\
\hline DBS-Cons Perception & -.004 & .45 & -.002 & -.079 & .937 \\
\hline SES-Sun Avoidance & .135 & .062 & .078 & 2.182 & .029 \\
\hline SES-Sunscreen Use & .360 & .047 & .293 & 7.653 & .000 \\
\hline SES-Hat Use & .187 & .080 & .079 & 2.330 & .020 \\
\hline $\mathbf{R}$ & \multicolumn{5}{|c|}{.580} \\
\hline $\mathbf{R}^{2}$ & \multicolumn{5}{|c|}{.336} \\
\hline $\mathbf{F}$ & \multicolumn{5}{|c|}{85.081} \\
\hline $\mathbf{p}$ & \multicolumn{5}{|c|}{.000} \\
\hline DW* (1.5-2.5) & \multicolumn{5}{|c|}{1.850} \\
\hline
\end{tabular}

*Durbin Watson

According to the structural equation model, the fit indices of the model 1 were found to be as RMSEA $=.001$, GFI $=$ $1.00, \mathrm{CFI}=.92, \mathrm{RFI}=.99, \mathrm{NFI}=.99, \mathrm{NNFI}=.99$, and $\mathrm{IFI}=.99($ Table 5$)$.

Table 5. The Fit Indices of the Structural Equation Model

\begin{tabular}{cccccccccccc}
\hline & $\mathbf{X}^{\mathbf{2}}$ & $\mathbf{d f}^{\mathbf{a}}$ & $\mathbf{x}^{\mathbf{2} / \mathbf{d f}}$ & $\mathbf{p}$ & $\mathbf{G F I}^{\mathbf{b}}$ & $\mathbf{C F I}^{\mathbf{c}}$ & $\mathbf{N F I}^{\mathbf{d}}$ & TLI $^{\mathbf{e}}$ & RFI $^{\mathbf{f}}$ & IFI $^{\mathbf{2}}$ & RMSEA $^{\mathbf{h}}$ \\
\hline $\begin{array}{c}\text { Model } \\
\mathbf{1}\end{array}$ & .006 & 1 & .006 & .937 & 1.000 & .99 & .99 & .99 & .99 & .99 & .001 \\
\hline
\end{tabular}

a: Degree of Free; b: Goodness of Fit Index; c: Comparative Fit Index; d: Normed Fit Index; e: TLI (NNFI): Trucker-lew1s Index; f: Relative

Fit Index; g: Incremental Fit Index; h: Root Mean Square Error of Approximation

According to the model created, a moderate positive correlation was found between DBS pros perception and SES sun avoidance and use of sunscreen, whereas a low positive correlation was found between DBS pros perception and SES hat use. A low positive correlation was found between DBS cons perception and SES avoidance from the sun and use of sunscreen, while there was a low negative correlation between DBS cons perception and SES hat use. A low positive correlation was determined between DBS pros perception and SPBS. In addition, there was a low positive correlation between SES avoidance from the sun, sunscreen and hat use and SPBS (Figure 1). 


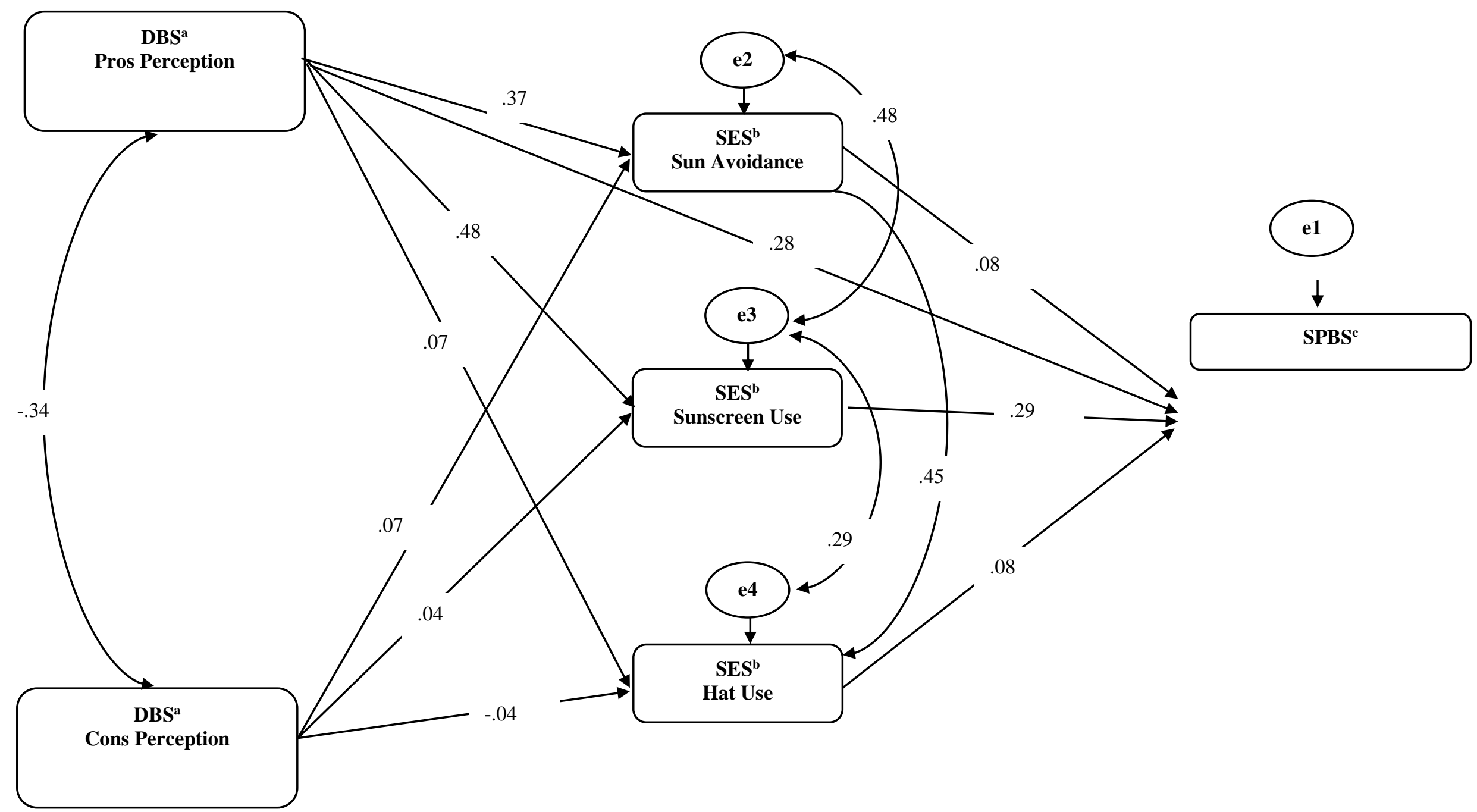

Figure 1. The Structural Equation Model between the Variables

a: Decisional Balance Scale; b: Self-Efficacy Scale; c: Sun Protection Behavior

Scale 


\section{Discussion}

The findings of this study show the effect of high school students' self-efficacy and perception of sun protection on their sun protection behaviors.

When the relationship between sun protection self-efficacy and perceptions and sun protection behaviors were examined, there were significant correlations among SPBS and DBS pros perceptions, SES avoidance of the sun, sunscreen use, and SES hat use $(\mathrm{p}<.001)$. When the literature was examined, it showed that the use of sunscreen and a hat increases sun protection behaviors. In addition, it was observed that sun protection behaviors increase as the perceptions of benefits from sun protection increase (9-12). There is a parallel between the information presented in this study and the literature.

By considering the correlations between the variables in this study, the effect of high school students' self-efficacy and perceptions for sun protection on their sun protection behaviors was defined as a model.

In Model 1, as the subscale scores obtained from the Sun Protection Self-Efficacy Scale (SES) (avoidance from the sun $\beta=.078$, using sunscreen $\beta=.293$, wearing a hat $\beta=.079$ ) and the scores obtained from the perception of cons subscale of the Decisional Balance Scale (DBS) for Sun Protection $(\beta=.261)$ increased, the sun protection behaviors of the students increased as well.

Self-confidence, perception of decision-making, and self-efficacy have an important role in changing and developing sun protection behaviors in high school students. A high level of self-efficacy, which is one of the tools that determine the level of change, increases the ability of an adolescent to stand against negative behaviors despite stimulating situations. In addition, as the self-efficacy of the adolescent increases, their confidence not to resume risky habits such as ignoring sun protection increases (9-12). The decisional balance, which is an important variable in changing and developing sun protection behaviors, reveals the perceptions of pros-cons of behavioral change. Pros reflect the positive aspects of behavioral change and cons reflect obstacles against change $(9,12)$. As the adolescent's perception of pros increases, the level of exhibiting sun protection behaviors increases as well. In addition, as the perception of cons decreases, the obstacles faced during exhibiting sun protection behaviors decrease. Thus, students with high self-efficacy and improved perception of pros-cons exhibit more sun protection behaviors. The literature supports the finding that sun protection behaviors increase as the scores for sun protection self-efficacy and the perception of the pros of sun protection increase in model $1 \quad(11,19,20)$. In this study, it was observed that while the sun protection behaviors increased as the students' perception of the pros increased, the perception of cons did not affect the sun protection behaviors ( $\mathrm{p}>$.050). It is thought that the reason why the perceptions of cons did not have an influence was due to the fact that the province where the study was carried out is in a region with high solar values and high temperatures and that the adolescents are knowledgeable about the harms of sunbathing without using sunscreen.

Fit statistics were used to determine how well the models may explain the data. These tested conformity of the model with the statistics obtained from the data. An increase in fit statistics determines conformity of the model (21, 22). According to the structural equation model created, there was a fit between the variables (Table 2, Figure 1). For the model, the fit indices (GFI, NFI, RFI, CFI, and IFI) were greater than .90, and the RMSEA was less than .080. In the literature, a model fit indicator (GFI, CFI, RFI, NFI, NNFI, and IFI) that is greater than .90, X2/DF of less than 5, and a RMSEA value of less than .08 are considered to be good fit indicators $(21,23)$. The findings of this study were consistent with the literature $(21,22)$. The fit indices indicate how well the predetermined theoretical model explained the data obtained. In the literature, the support of the results predicted by the draft model with the statistical model reveals that the supposed relationships exist in real life. It has been observed that as the self-efficacy and decision-balance perceptions of adolescents increase, sun protection behaviors increase $(10,11)$. As a result of the analysis, it was determined that as the self-efficacy and decision-balance perceptions of adolescents increased, sun protection behaviors also increased. It is thought that the model developed is compatible with adolescents' development of sun protection behaviors in real life.

\section{Conclusion}

As the study location has lots abondence of sunlight and is a holiday destination especially in the summer, it is important to identify the risks that may cause skin cancer development in adolescents, determine sun protection behaviors, and implement appropriate prevention programs. As adolescents' self-efficacy levels and perceptions of the pros and cons increase, their likelihood of exhibiting sun protection behaviors increases as well. For this reason, in adolescent education, it is important to design and disseminate educational programs consisting of interventions that will increase adolescents' self-efficacy and perceptions of decision-making.

In addition, making environmental arrangements is one of the important initiatives to be implemented for sun protection. For this reason, the provision of shadow structures in recreation areas such as pools and beaches, cultivation of shade trees, provision of sunscreen equipment are among the environmental regulations that will be applied to protect from the sun. The implementation of interventional programs is recommended, in which multi-component interventions would be applied to increase self-efficacy and decision-balance perceptions of adolescents. Thus, it is thought that the sun protection behaviors of adolescents will increase and the incidence of skin cancer will decrease. It is also suggested that multi-component intervention programs should be planned and conducted with a multidisciplinary team.

\section{Limitations}

There were same limitations to this the study. First, it was performed only in one region of Turkey, using convenience sample methods focused on adolescent self-reporting, and not using a longitudinal study method. Therefore, the results of this study can only be generalized to the studied sample. 


\section{Implication for Nursing Practice}

The implementation of interventional programs is recommended, in which multi-component interventions would be applied to increase self-efficacy and decision-balance perceptions of adolescents. Thus, it is thought that the sun protection behaviors of adolescents will increase and the incidence of skin cancer will decrease. It is also suggested that multi-component intervention programs should be planned and conducted with a multidisciplinary team.

\section{Information}

This study was approved by the Institutional Review Board of the University (IRB approval number: 4475-GOA-2019/03-34) (date: 13.02.2019). All authors contributed to the study conception and design. All authors read and approved the final manuscript. AAK: study design, data collection, statistics, results interpretation, writing the manuscript, MB: study design, statistics, results interpretation, writing the manuscript SK: study design, data collection, statistics, results interpretation, writing the manuscript.

\section{Conflict of Interest}

There is no conflict of interest among the authors. The authors received no financial support for the research, authorship, and/or publication of this article.

\section{References}

1. Ultraviolet radiation and the INTERSUN program, World Health Organization (WHO), 2012. URL: http://www.who.int/uv/faq/ skincancer/en/index1.html. Erişim Tarihi: 01.07.2020.

2. Reports Largest One-year Drop in Cancer Mortality, American Cancer Society, Facts \& Figures 2020. URL: https://www.cancer.org/latest-news/facts-and-figures-2020.html. Erişim Tarihi: 01.07.2020.

3. Gültekin M, Boztas G. Türkiye Cumhuriyeti Sağlık Bakanlığı, Türkiye Halk Sağlığı Kurumu, Kanser Daire Başkanlığı Türkiye Kanser İstatistikleri. 2014. URL: http:// kanser.gov.tr/Dosya/ca_istatistik/2009kanseraporu.pdf. Erişim Tarihi: 01.07.2020.

4. Wehner MR. Sunscreen and melanoma prevention: Evidence and expectations. The British Journal of Dermatology 2018; 178(1): 15 .

5. Glenn BA, Lin T, Chang LC, Okada A, Wong WK, Glanz K et al. Sun protection practices and sun exposure among children with a parental history of melanoma. Cancer Epidemiol Biomarkers Prev 2015;24(1): 169-177.

6. Sümen A, Öncel S. Deri kanseri ve güneşten korunmaya yönelik öğrencilerle ilgili yapılan çalışmalar: Literatür incelemesi. Dokuz Eylül Üniversitesi Hemşirelik Fakültesi Elektronik Dergisi 2014; 7(2): 78-91.

7. St. George SM, Wilson DK, Van Horn ML. Project SHINE: Effects of a randomized family-based health promotion program on the physical activity of African American parents. J Behav Med 2018;41:537-549.

8. Prochaska JJ, Spring B, Nig CR. Multiple health behavior change research: an introduction and overview. Preventive Medicine 2008;46(3):181-188.

9. Prochaska JO, Reddin CA, Evers KE. The transtheoretical model and stages of change. Health Behavior: Theory, Research, and Practice 2015:125-148.

10. Grossman DC, Curry SJ, Owens DK, Barry MJ, Caughey AB, Davidson KW et al. Behavioral counseling to prevent skin cancer: US Preventive Services Task Force recommendation statement. Jama 2018; 319(11): 1134-1142.

11. Aygun O, Ergun A. Decisional balance and self-efficacy for sun protection: Measurement among Turkish adolescents. Nursing Research 2014;63(5):309-319.

12. saes da Silva E, Tavares R, da silva Paulitsch F, Zhang L. Use of sunscreen and risk of melanoma and non-melanoma skin cancer: a systematic review and meta-analysis. European Journal of Dermatology 2018; 28(2): 186-201.

13. Aygün Ö, Ergün A. Investigation of 6-8. grades secondary school students of the sun protection behaviors in Sakarya province. TAF Preventive Medicine Bulletin 2016;15:312-321.

14. Maddock JE, Ross JS, Redding CA, Meier KS, Velicer WF, Prochaska JO. Development of transtheoretical model constructs for sun protection behaviors among adolescents. Ann Behav Med 1998;20(Poster):S208.

15. Aygun O, Ergun A. Validity and reliability of sun protection behavior scale among Turkish adolescent population. Asian Nurs Res (Korean Soc Nurs Sci) 2015;9(3):235-242.

16. Velicer WF, DiClemente CC, Ross JS, Prochaska JO. Relapse situations and self-efficacy: An integrative model. Addictive Behaviors 1990; 15:271-283.

17. Zhou H, Deng Z, Xia Y, Fu M. A new sampling method in particle filter based on Pearson correlation coefficient. Neurocomputing 2016; 216: 208-215.

18. Sunscreen FAQS, The American Academy of Dermatology. https://assets.ctfassets.net/1ny4yoiyrqia/4xAHF2HbKPsmHnL0CTZcFS/b5e2a00d2376dc596088f764e8a1f0f0/Sunscreen _FAQ_5-19.pdf. Erişim Tarihi:29.06.2020

19. Jones SE, Guy GP. Sun safety practices among schools in the United States. JAMA Dermatology 2017; 153(5): $391-397$. 
Araştırma

20. Guy GP, Berkowitz Z, Jones SE, Watson M, Richardson LC. Prevalence of indoor tanning and association with sunburn among youth in the United States. JAMA Dermatology 2017; 153(5): 387-390.

21. Kline RB. Principles and Practice of Structural Equation Modeling. Fourth Edition. Guilford Publications; 2015.

22. Özdamar K. Paket Programları ile İstatiksel Veri Analizi-II. 10. Basım. Eskişehir: Nisan Kitabevi; 2017.

23. Civelek M. Yapısal Eşitlik Modellemesi Metodolojisi. 1. Basım. İstanbul: Beta Yayınları; 2018 